\title{
Pendekatan Kasus Banyaknya Penyebaran Berita Hoax di Media Sosial \\ Menggunakan Teori Bahasa dan Sosialitas
}

Andrianus Kurniawan

\section{Program Studi Teknik Industri Universitas Katolik Widya Mandala Madiun \\ Andrianuskurniawan20@gmail.com}

\begin{abstract}
Abstrak
Di era modern seperti sekarang ini manusia sangat mudah untuk memperoleh berbagai informasi, hal itu juga yang dialami oleh masyarakat Indonesia sekarang ini. Dengan semakin berkembangnya zaman masyarakat Indonesia akan sremakin mudah mendapatkan apa yang diinginkan. Hal itu juga terjadi dalam bidang komunikasi. Masyarakat akan semakin mudah untuk berkomunikasi dengan orang yang jauh dari kita. Tetapi dengan hal itu juga banyak dampak negatif yang ditimbulkan dengan adanya perkembangan komunikasi zaitu zaman sekarang ini banyak berita hoax yang beredar di media sosial. Banyak penyalahgunaan bahasa dan fungsi bahasa dan sosialisasi untuk kepentingan negatif oleh pelaku di media sosisal. Sehingga sebagai masyarakat kita harus bijak dalam penggunaan media sosial agar tidak mudah termakan oleh hasutan. Kata kunci: Banyaknya Berita Hoax di Media Sosial, Bahasa, dan Sosialitas
\end{abstract}

\section{A. Latar Belakang}

Di era modern seperti sekarang ini manusia sangat mudah untuk memperoleh berbagai informasi, hal itu juga dialami oleh masyarakat Indonesia sekarang ini. Dengan semakin berkembangnya zaman masyarakat Indonesia akan semakin mudah mendapatkan apa yang. Dengan semakin pesatnya perkembangan zaman, masyarakat juga akan semakin mudah mendapatkan berbagai informasi yang diinginkan baik itu melalui media cetak maupun media elektronik. Hal itu juga yang membuat kebutuhan masyarakat akan media sosial merupakan kebutuhan yang sangat penting. Dengan semakin banyaknya media sosial yang beredar membuat komunikasi antar masyarakat juga semakin mudah. Seperti Whatsapp dan Instagram contohnya yang hampir digunakan setiap hari oleh masyarakat sehingga masyarakat seperti kurang lengkap apabila tidak memakai media sosial tersebut. 
Tetapi selain memiliki banyak dampak positif, ternyata dengan hadirnya banyak media sosial di Indonesia juga banyak menimbulkan berbagai dampak negatif bagi masyarakat Indonesia yaitu penyebaran berita hoax yang semakin mudah. Di era media sosial seperti saat ini sebaran hoax menjadi sesuatu yang sangat serius karena terlampau mudah untuk diakses. Dengan semakin mudahnya masyarakat Indonesia mendapatkan berbagai macam berita dari sumber manapun maka masyarakat juga akan semakin mudah ,mendapatkan berita bohong. Banyaknya berita bohong yang ada di masyarakat yang dipublikasikan oleh oknum-oknum yang tidak bertanggung jawab akan menimbulkan kerusuhan di sekitar masyarakat Indonesia.

Seperti contohnya berita palsu tentang server KPU yang telah di Setting untuk memenangkan salah satu pasangan calon presiden dan wakil presiden yang sangat viral beberapa hari ini. Pada akhirnya kedua tersangka penyebar berita palsu tersebut ditangkap oleh polisi, mereka ditetapkan sebagai tersangka untuk kasus penyebaran berita palsu.

Dengan semakin banyaknya berita palsu yang berdear di Indonesia akan semakin membuat kegaduhan karena tidak sedikit masyarakat yang akan terhasut oleh berita bohong yang disebarkan oleh pelaku. Berita hoax yang ada di media sosial akan berdampak buruk bagi masyarakat, karena dengan adanya berita tersebut akan membuat masyarakat sering membuka media sosial untuk membaca sesuatu hal yang tidak penting, sehingga waktu yang dimiliki akan terbuang siasia. Berita bohong di media sosial juga akan menimbulkan kegaduhan karena banyak juga berita bohong yang tersebar di media sosial yang mengandung unsur SARA sehingga akan merusak persatuan dan kesatuan bangsa Indonesia. Selain itu berita bohong yang banyak tersebar di berbagai media sosial akan merugikan pihak tertentu dan juga akan memberikan keuntungan pada pihak tertentu juga, dan juga terkadang banyaknya berita bohong juga akan membuat kepercayaan masyarakat akan fakta yang terjadi menjadi turun.

\section{B. Pembahasan Masalah}

Dengan banyaknya berita bohong yang berdar di media sosial sebaiknya masyarakat lebih berhati-hati dan selektif dengan judul yang provokatif atau judul yang menyesatkan. Masyarakat juga harus memiliki rasa penasaran yang baiki, 
sehingga jika mengetahui ada berita yang berdear masyarakat tidak langsung untuk menyebarkan kembali, melainkan akan menyaring berita tersebut, dan juga mengecek apakah berita tersebut merupakan berita benar atau berita bohong. Selain itu masyarakat haruse mengecek keaslian alamat dan keaslian sumber dan foto yang ada dalam bertia sehingga masyarakat tidak akan mudah terprovokasi dengan berita-berita bohong yang beredar di media sosisal. Jadi diharapkan masyarakat Indonesia terutama harus lebih selektif dalam memilih suber informasi terutama sumber informasi yang didapatkan dari berbagai sumber yang ada di media sosial karena dengan melakukan hal kecil tersebut masyarakat akan membantu terciptanya kedamaian dan juga kerukunan antar masyarakat Indonesia. Dan juga masyarakat Indonesia sebaiknya harus lebih bijak dalam penggunaan media sosial sehingga dengan begitu penyebaran berita bohong juga akan dapat lebih diminimalkan.

Dengan kecanggihan teknologi yang ada sekarang ini, dan semakin maraknya penggunaan media sosial, banyak pelaku yang salah menggunakan kecanggihan teknologi, dan media sosial untuk hal-hal yang negatif yaitu dengan menyebarkan berita-berita bohong di media sosial. Para pelaku tersebut berkomunikasi menggunakan bahasa yang seharusnya digunakan untuk berkomunikasi kebaikan, tetapi oleh pelaku digunakan berkomunikasi untuk menyebarkan berita bohong. Selain itu pelaku tersebut dalam bersosialisasi dengan menggunakan media sosial yang ada bukan untuk fungsi komunikasi dalam hal yang positif, tetapi menggunakan media sosial untuk menyebarkan berbagai berita bohong.

Bahasa merupakan semacam gudang persediaan yang memungkinkan munculnya sistem bahasa, sehingga orang dapat mempelajari bahasa. Bahasa menghadirkan barang, keadaan, dll dalam cara beradanya yang berbeda-beda. Bahasa mengkomunikasikan sesuatu secara verbal dan non verbal yang melukiskan sesuatu yang sedapat mungkin sesuai dengan kenyataan. Bahasa juga menyingkapkan kehendak. Sosialitas adalah kebersamaan antar individu. Sosialitas menjadi cara untuk menunjukan kehidupan bersama. Banyaknya aktivitas penyampain pesan melalui media sosial juga akan mendorong dan memotivasi para warganet untuk memainkan gawainya merangkai kata-kata 
menjadi sebuah kalimat. Tetapi seringkali juga sering ditemui kesalahan dalam penggunaan bahasa sehingga menimbulakan miskomunikasi antara pembuat dan pembaca. Selain itu dalam penggunaaan bahasa dalam berkomunikasi juga seringkali dijumpai penyalahgunaan bahasa seperti penyebaran berita bohong. Banyak warga yang tidak bertanggung jawab yang menyalahgunakan fungsi komunikasi dengan bahasa untuk keperluan yang negatif. Hanya untuk mendapatkan keuntungan tertentu atau untuk menguntungkan suatu pihak banyak pelaku yang rela untuk menyebarkan berita bohong sehingga dapat memecah persatuan dan kesatuan bangsa Indonesia. Selain itu para pelaku juga menyalahgunakan fungsi media sosial yang seharusnya untuk bersosialisasi dengn masyarakat lainnya, tetapi oleh pelaku media sosial digunakan untuk menyebarkan banyak berita-berita bohong di media sosial.

Seharusnya media sosial dapat digunakan untuk penyimpanan informasi yang sangat mudah menyebar melalui media sosial. Dengan adanya media sosial kita dapat mengetahui berita atau mencari informasi dari berbagai sumber dan dari Negara manapun dengan mudah, hanya dengan hitungan menit kita sudah dapat memperoleh informasi yang ingin kita dapatkan. Selain itu dengan adanya media soisal kita dapat dengan mudah berkomunikasi dengan masyarakat manapun sehingga kita akan lebih meminimalkan biaya. Sehingga media sosial dapat menyambung silaturahmi baik itu dengan sahabat ataupun dengan sauadara yang jauh dari kita. Contohnya dengan media sosial kita dapat berkomunikasi dengan sahabat ataupun saudara yang jauh dari kita dengan cepat dan mudah untuk melepaskan rindu, sehingga kita tidak perlu berpergian jauh untuk sekedar berkomunikasi. Selain itu dengan adanya media sosial kiat juga kan lebih mudah jika ingin berbelanja apabila kita sedang malas untuk keluar rumah.

Tetapi banyak orang-orang yang tidak bertanggung jawab yang menggunakan media sosial untuk tindak kejahatan yaitu menyebarkan berbagai berita bohong untuk memperoleh keuntungan tertentu. Selain itu dengan banyaknya media sosial akan membuat seseorang lebih individualistis dan mereka menjadi tidak sadar akan lingkungan di sekitarnya, contohnya banyak orang yang aktif menggunakan media sosial dan juga mempunyai teman yang banyak di media sosial, dan setiap kegiatannya pasti di posting di media sosial, tetapi 
berbanding terbalik dengan dunia nyata . Dalam media sosial juga sering terjadi penyalahgunaan bahasa karena sering dalam media sosial banyak menggunakan bahasa yang informal. Media sosial juga akan membuat masyarakat menjadi tidak bisa membagi waktu karena waktunya akan habis terbuang sia-sia oleh media sosial yang ada, contohnya banyak masyarakat yang sibuk sendiri dengan gawainya masing-masing dan tidak menghiraukan orang-orang di sekitarnya. Oleh karena itu kita harus benar-benar pandai dan bijak dalam penggunaan media sosial yang ada jangan sampai kita dikuasai oleh media sosial, sehingga kita harus dapat menggunakan media sosial untuk sesuatu yang bermanfaat bagi kita dan orang lain, jdan jug harus selektif dengan apa yang ada di dalam media sosial. Jangan sampai kta mudah terhasut oleh banyak hal negatif yang ada di media sosial. Kita harus dapat menyaring berbagai informasi yang kita dapatkan darai media sosial yang ada.

Jadi dengan banyaknya dampak positif dan negatif yang terdapat di berbagai media sosial yang ada sebaiknya kita harus bijak dalam penggunaan media sosial, kita haru selektif dalam memilih sumber informasi yang ingin kita peroleh, dan juga kita harus mengecek sumber informasi tersebut, selain itu kita juga harus melihat keaslian gambar atau foto yang ada dalam media sosial, jadi kita tidak boleh mudah untuk terprovokasi jika kita mendapatkan sebuah berita yang ada di dalam media sosial. Sehingga dengan begitu kita kita juga turut dalam menjaga persatuan dan kesatuan bangsa Indonesia karena kita tidak mudah terbawa emosi dengan banyaknya berita bohong yang terdapat di berbagai media sosial.

Selain itu kita juga harus menggunakan media sosial dengan seperlunya saja sehingga kita tidak diperbudak dengan adanya media sosial. Media sosial digunakan untuk menjalin komunikasi dengan orang yang jauh dari kita dan juga untuk mempermudah kehidupan kita bukan untuk digunakan secara berlebihan karena dapat membuat kiat lupa akan lingkungan sekitar kita karena terlalu fokus dengan media sosial masinh-masing, dan media sosial akan membuat kita menjadi orang yang individualistis jika kita menggunakan media sosial secara berlebihan dan tidak tahu batasannya. Kita harus ingat juga bahwa kita berada di dunia nyata bukan hanya di media sosial jadi komunikasi dan sosialisasi di dunia nyata itu 
juga sangat penting dilakukan. Kita juga juga harus menjaga etika dalam penggunaan media sosial, dan kita sendiri juga dalam menggunakan media sosial tidak boleh menyebarkan isu SARA dan berita bohong. Tetapi sebaiknya kita dapat menggunakan media sosial sebagai hasil promosi bagi karya yang telah kita buat, dan juga kita dapat menggunakan media sosial untuk membangun jaringan antar masyarakat.

Selain itu kita dapat menangkal berita bohong dengan bergabung dengan komunitas anti hoax jadi dengan itu kita dapat memperoleh pengarahan dan penyuluhan yang benar tentang berita atau fenomena yang beredar di media sosial yang ada, dan juga dengan bergabung dengan komunita kita juga dapat mendiskusikan pabila ada suatu berita yang penuh kontroversi, dengan begitu pemikiran kita akan terbuka. Langkah selanjutnya jika kita menemukan berita bohong dan memiliki bukti yang kuat kita juga dapat melaporkan konten ataupun alamat berita tersebut kepada Kominfo. Sehingga sebuah langkah kecil dari kita akan sangat berharga dan bermakana guna membantu penangkalan penyebaran berita bohong yang akhir-akhir ini memang meresahkan berbagai kalangan masyarakat. Jadi yang terpenting adalah bijak dalam penggunaan media sosial dan saring informasi yang akan kita peroleh. 


\section{Daftar Pustaka}

Dewantara, Agustinus. "Filsafat Moral (Pergumulan Etis Keseharian Hidup Manusia)." (2017). 